Artigo original

Hegemonia - Revista Eletrônica de Relações Internacionais do Centro

Universitário Unieuro

ISSN: $1809-1261$

UNIEURO, Brasília, número 13, 2014, pp. 159-201.

Recebido em: 2/3/2014

Avaliado em:8/4/2014

Aprovado em: 13/5/2014

\title{
A consolidação da América do Sul como uma Zona de Paz: Um estudo sobre o Conselho de Defesa Sul-americano e seus impactos no complexo regional de segurança
}

ALMEIDA, Mayana Ribeiro de ${ }^{1}$

Resumo: O presente artigo desenvolve uma análise acerca do Conselho de Defesa Sul-Americano no cenário de segurança regional, compreendido como relativamente pacífico pela baixa incidência de guerras interestatais, porém ainda distante de uma zona de paz ou comunidade de segurança consolidada. Nesse contexto, a criação do Conselho de Defesa no âmbito da UNASUL, enquanto um canal de diálogo permanente para os países da região discutirem as questões relativas a defesa, é um importante instrumento de promoção da confiança mútua. No entanto, os desafios deste órgão perpassam não apenas pelas distintas percepções dos Estados da região quanto à defesa mas também quanto ameaça e segurança. $O$ entendimento e aprofundamento da cooperação no âmbito do Conselho de Defesa constituem um importante passo para a consolidação da região como uma zona de paz.

Palavras-chave: Conselho de Defesa Sul-Americano. Complexo Regional de Segurança. Comunidade de Segurança. Mercosul. Integração.

Abstract: This article provides an analysis of the South American Defense Council in the regional security scenario understood as relatively peaceful because of the low incidence of interstate wars, however still far from a zone of peace or a security community consolidated. In this context, the creation of the UNASUR South American Defense Council, a permanent channel of dialogue to discuss defense issues, is an important instrument to promote mutual trust. However, the challenges of this council permeate not only the different perceptions in South America related to defense, but also related to threat and security. The understanding and deepening of cooperation under Defense Council is an important step towards the consolidation of the region as a zone of peace.

Keywords: South American Defense Council. Regional Security Complex.

1 Especialista em Relações Internacionais. 


\section{Artigo original}

Hegemonia - Revista Eletrônica de Relações Internacionais do Centro

Universitário Unieuro

ISSN: $1809-1261$

UNIEURO, Brasília, número 13, 2014, pp. 159-201.

Security Communities. Mercosur. Integration.

INTRODUÇÃO

Com dinâmicas e características próprias, a América do Sul conseguiu desenvolver mudanças pacíficas nas relações entre os Estados, dissolvendo algumas hipóteses de conflitos presentes por séculos na região. Os esforços em direção ao aprofundamento dos processos de cooperação e integração regional resultaram na criação de importantes organismos regionais como: o MERCOSUL e a UNASUL. No âmbito do último, a fim de promover a cooperação na esfera de defesa, a região criou o Conselho de Defesa Sul-Americano, estabelecendo um permanente canal de diálogo para tratar de um tema sensível, contribuindo para o fortalecimento da confiança mútua entre os países da região.

O objetivo deste artigo é desenvolver análises acerca dos impactos que o Conselho de Defesa promove no complexo de segurança sul-americano, expondo seus desafios e avanços. O argumento principal é que os desafios do CDS perpassam por questões que extrapolam a esfera de defesa, englobando as diferentes percepções de cada ator da região sobre ameaça, defesa e segurança. A consolidação do organismo contribui para fortalecer a confiança mútua fundamental em uma Zona de Paz ou Comunidade de Segurança.

Dessa forma, o presente estudo foi dividido em três partes, além das considerações finais. Inicialmente é realizada uma revisão teórica acerca dos Complexos Regionais de Segurança e das Comunidades de Segurança, 


\section{Artigo original}

Hegemonia - Revista Eletrônica de Relações Internacionais do Centro Universitário Unieuro

ISSN: $1809-1261$

UNIEURO, Brasília, número 13, 2014, pp. 159-201. utilizadas de forma complementar nos propósitos deste trabalho. Na segunda parte desenvolve-se uma análise acerca das dinâmicas de segurança antecedentes ao CDS, demonstrando as diferenças entre as sub-regiões, Cone Sul e Andina. Por fim, desenvolve-se uma análise acerca do Conselho de Defesa, englobando as dificuldades dos processos negociadores, a presença dos Estados Unidos na Região, os desafios tradicionais e as "novas" ameaças que perpassam pela consolidação do organismo, assim como pela consolidação da região como uma zona de paz.

1 REFERENCIAIS TEÓRICOS: OS COMPLEXOS REGIONAIS DE SEGURANÇA E A FORMAÇÃO DAS COMUNIDADES DE SEGURANÇA

As estruturas do cenário internacional não são estáticas, assim como também não são as percepções que os atores têm um do outro. Wendt afirma a existência de pelo menos três tipos de culturas de anarquia: hobbesiana, lockiana e kantiana, nas quais imperam as lógicas de inimizade, rivalidade e amizade, respectivamente. Os conflitos de interesses sempre estiveram presentes nas relações internacionais. Porém, a guerra nem sempre foi uma alternativa provável e o outro nem sempre fora reconhecido como uma ameaça existencial.

As percepções de cada ator em relação ao outro é construída baseada no conhecimento que se tem. Este, por sua vez, é fruto das interações. O conhecimento pode gerar e aprofundar desavenças, mas também pode tornar o outro mais confiável e a confiança mútua é um pressuposto para a paz. Wendt afirma que "As ameaças sociais são construídas, não naturais" (1992, p. 405). O que um ator define como ameaça não necessariamente é percebido da mesma forma pelos demais atores e as reações em cadeia são mais complicadas porque $A$ pode securitizar $B$ como uma ameaça, com o efeito que C torna-se preocupado e securitiza A como uma ameaça (BUZAN; WÆVER, 
Artigo original

Hegemonia - Revista Eletrônica de Relações Internacionais do Centro

Universitário Unieuro

ISSN: $1809-1261$

UNIEURO, Brasília, número 13, 2014, pp. 159-201.

2003).

Segundo Tavares "a maioria das ameaças e problemas de segurança são primeiramente regionais, mais que, locais, nacionais ou globais" $(2010$, p.3). Muitos estudos de segurança privilegiaram os dois últimos níveis (nacional e global). Porém, é no nível regional que estes dois extremos interagem e que a maior parte da ação ocorre (BUZAN; WÆEVER, 2003). A Teoria dos Complexos Regionais de Segurança desenvolve-se sob esta premissa. "A ideia central da TCRS é que, como a maioria das ameaças viaja mais facilmente sobre curtas distâncias do que sobre mais longas, a interdependência de segurança é normalmente modelada em clusters de base regional: Complexos de segurança" (BUZAN; W/EVER, 2003, p. 4). O mundo seria composto de diversos Complexos Regionais de Segurança, além dos estados insuladores estados que se encontram na "zona de indiferença" entre diferentes complexos, mantendo suas dinâmicas de segurança separadas (ABDUL-HAK, 2013). A América do Sul formaria um complexo.

Os Complexos Regionais de Segurança (CRS) são definidos como "um conjunto de unidades cujos principais processos de securitização ou dessecuritização, ou ambos, estão tão interligados que seus problemas de segurança não podem ser razoavelmente analizados ou resolvidos de maneira separada dos demais" (BUZAN; WÆVER; 2003, p. 44). Esse conceito é resultado de uma reformulação do conceito original, cujos focos eram 0 Estado e a esfera político-militar da segurança, para abranger novos atores e os diversos setores da segurança. O reconhecimento multissetorial da segurança englobava cinco dimensões: política e militar (vertentes tradicionais), econômica, societal e ambiental. Para Villa e Santos (2010, p. 132-133), com relação a este alargamento, "O mais importante é que se abriu um novo repertório que permite que a segurança nacional seja 'desencapsulada' de um significado fixo, muito limitado às percepções de ameaças específicas ao setor militar e, eventualmente ao setor político. Flui-se assim para significados multidimensionais". O conceito de segurança não 


\section{Artigo original}

Hegemonia - Revista Eletrônica de Relações Internacionais do Centro Universitário Unieuro

ISSN: $1809-1261$

UNIEURO, Brasília, número 13, 2014, pp. 159-201.

apenas possui diversos setores interdependentes, "como também pode mudar segundo a conjuntura histórica e política" (ABDUL-HAK, 2013, p. 34).

Em relação aos processos de securitização, eles ocorrem quando "confere-se a uma questão política um caráter emergencial, ou seja, transforma-se um problema da esfera política numa questão de segurança" (VILLA; SANTOS, 2010, p. 122). Quando um ator securitiza uma questão, ele passa a tratá-la como uma ameaça existencial, justificando medidas extremas. Nem sempre essa ameaça existencial é real, porém, ela é construída como tal e aceita por determinada parte da população. "Para que a ameaça seja identificada é necessário que ocorra um processo intersubjetivo de reconhecimento pelos atores securitizadores e pelas sociedades" (VILLA; SANTOS, 2010, p. 122). Segundo Buzan, Wæver e Wilde (1998), a securitização é inevitável em alguns casos, por exemplo, frente a um agressor implacável. Além disso, pode chamar atenção para determinados problemas pelo seu caráter prioritário. Porém, o ideal é que a política, a partir dos seus procedimentos de rotina, se desdobre sobre ameaças específicas não thes dando imediatamente um caráter de vida ou morte. Dessa forma, os autores afirmam a relevância dos processos de dessecuritização, ou seja, retirar uma questão da esfera de segurança e tratá-la dentro dos procedimentos políticos normais.

As dinâmicas de securitização fazem parte de um complexo regional de segurança, cuja estrutura essencial engloba quatro variáveis: 1) limites, que diferenciam o CRS de seus vizinhos; 2) estrutura anárquica, ele deve ser composto de duas ou mais unidades; 3) polaridade, que se refere distribuição de poder entre as unidades; 4) construção social, que abrange os padrões de amizade-inimizade entre as unidades (BUZAN, WÆVER, 2003).

Em geral os CRS podem ser de dois tipos: padrão ou centrado. O primeiro é formado por dois ou mais poderes, não contendo uma potência global, e a agenda de segurança é predominantemente político-militar. 0 segundo pode ter três formas (possivelmente quatro): 1) unipolar, centrado 


\section{Artigo original}

Hegemonia - Revista Eletrônica de Relações Internacionais do Centro Universitário Unieuro

ISSN: $1809-1261$

UNIEURO, Brasília, número 13, 2014, pp. 159-201.

em uma grande potência; 2) unipolar, centrado em uma superpotência; 3) uma região integrada por instituições. A quarta forma seria um complexo centrado em torno de uma potência regional. Porém, Buzan e Wæver (2003) não identificaram nenhum CRS desse tipo. Existem ainda os CRS em que grandes potências são pólos regionais, os quais podem ser bipolar ou multipolar, e os supercomplexos, nos quais existe um forte nível inter-regional de dinâmicas de segurança decorrente do transbordamento de uma grande potência dentro de regiões adjacentes (BUZAN, WÆVER, 2003).

A Teoria dos Complexos Regionais de Segurança contempla quatro níveis de análise, que juntos formam a "constelação de segurança". O primeiro nível corresponde ao âmbito doméstico dos estados que compõem a região, em particular as suas vulnerabilidades. O segundo nível corresponde às relações entre os estados que conformam a região. O terceiro refere-se à interação da região com regiões vizinhas. O último aborda a interação entre o complexo regional e as estruturas de segurança globais (BUZAN, WÆVER, 2003).

Os elementos da teoria dos CRS são definidos como padrões duráveis de amizade e inimizade, assumindo a forma de padrões subglobais e geograficamente coerentes de segurança interdependente (BUZAN, WÆVER, 2003). "O CRS não se limita a refletir padrões históricos de relacionamento, contudo, mas também altera o comportamento dos Estados que o integram" (ABDUL-HAK, 2013, p. 36). Em relação à amizade e inimizade, os padrões dos CRS podem ser conflitos em formação, regimes de segurança ou comunidade de segurança. Os regimes de segurança são princípios, normas e regras de conduta que refletem a convergência das expectativas dos atores de que a guerra e o uso da força podem ser atenuados a partir daqueles.

Segundo Buzan e Wæver (2003), um complexo regional deve conter a dinâmica de securitização. Porém, o desenvolvimento de uma comunidade de segurança é marcado por processos de dessecuritização. Segundo estes autores, contudo,

No mundo real, o caso extremo de dessecuritização total em 
Artigo original

Hegemonia - Revista Eletrônica de Relações Internacionais do Centro

Universitário Unieuro

ISSN: $1809-1261$

UNIEURO, Brasília, número 13, 2014, pp. 159-201.

uma região não é impiricamente significativo e, os casos mais maduros de comunidade de segurança hoje não são marcados por um esquecimento das preocupações de segurança, mas sim pela agregação consciente deles [...]. O Cone Sul na América do Sul está perto de criar uma comunidade de segurança com base na securitização principalmente de uma ameaça econômica externa, e disto decorrendo a necessidade de pacificação regional. A forma mais relevante de comunidade de segurança contém securitização ativa e regional, isso não é apenas de ator para ator, mas, uma securitização coletiva do desenvolvimento global da região (grifo meu) (BUZAN, W/EVER, 2003, p.57).

Buzan e Wæver concluem então, que uma comunidade de segurança não se desenvolve para além de um CRS, ao contrário, ela é um dos possíveis padrões que ele pode assumir. Enquanto a Teoria dos Complexos Regionais de Segurança desenvolve-se como uma teoria mais geral, concluindo que o mundo seria composto por diversos complexos, a teoria das Comunidades de Segurança desenvolve-se sob uma perspectiva mais específica, refletindo um padrão único de expectativas de mudanças pacíficas entre um grupo, que não necessariamente estão interligados por condições geográficas. Segundo Deutsch e seus colaboradores, uma comunidade de segurança é:

Um grupo de pessoas que se tornou "integrado". Por integração, queremos dizer o alcançe, em um território, de um "sentimento de comunidade" e de instituições e práticas fortes e disseminados o suficiente para assegurar, por um "longo" período de tempo, expectativas confiáveis de "mudança pacífica" entre sua população. Por "sentimento de comunidade", nos referimos a crença de uma parte de indivíduos em grupo que chegou a um acordo ao menos no seguinte ponto: que problemas socias comuns devem e podem ser resolvidos por "processos de mudança pacífica". Por "mudança pacífica" nos referimos a resoluções de problemas sociais, normalmente por procedimentos institucionalizados, sem o uso de força física em largaescala (DEUTSCH, 1957, p. 69).

Nem toda comunidade é uma comunidade de segurança. Para Adler e 


\section{Artigo original}

Hegemonia - Revista Eletrônica de Relações Internacionais do Centro Universitário Unieuro

ISSN: $1809-1261$

UNIEURO, Brasília, número 13, 2014, pp. 159-201.

Barnett (1998), o que diferencia uma comunidade de segurança das demais são as expectativas confiáveis de mudança pacífica entre seus membros. Deutsch (1957) argumenta a existência de dois tipos de comunidades de segurança: amalgamadas e pluralistas. No primeiro tipo, duas ou mais unidades independentes se unificam formalmente, com um governo comum. No segundo, as unidades mantém sua independência legal. Adler e Barnett (1998) classificam as comunidades pluralistas em duas. Primeiro, elas podem ser parcialmente integradas, ou seja, possuem apenas as características mínimas, significando dizer que seus membros mantêm expectativas confiáveis de mudanças pacíficas. Segundo, elas podem ser comunidades de segurança estreitamente integradas, o que exige maiores demandas. Nesse tipo de comunidade desenvolve-se uma sociedade de "ajuda mútua", na qual se constroem sistemas coletivos de acordos e um sistema de normas localizado entre os estados soberanos e o governo regional centralizado, englobando instituições supranacionais, transnacionais e nacionais comuns e mecanismos segurança coletiva (ADLER; BARNETT, 1998).

A evolução das comunidades de segurança reflete três fases: nascente, ascendente e madura. Segundo Adler e Barnett (1998), na primeira fase, os governos não buscam de forma explícita construir uma comunidade de segurança. Começam, porém, a pensar em como coordenar suas ações visando o aumento da segurança mútua, redução de custos das suas transações e promover intercâmbio e interações. Um Estado ou uma coalizão de Estados podem facilitar a evolução da comunidade e funcionar como um estabilizador. Nessa fase são criadas instituições e organizações, as quais têm papel fundamental como local de socialização e aprendizagem que contribuem direta e indiretamente para a construção de uma comunidade de segurança, pois, a partir das interações criam-se normas de conduta, mecanismos de controles e sanções que colaboram para a construção da confiança mútua (ADLER; BARNETT, 1998). "A capacidade de organizações multilaterais de segurança de aliviar o medo entre membros do grupo pode ser detectada em 
Artigo original

Hegemonia - Revista Eletrônica de Relações Internacionais do Centro

Universitário Unieuro

ISSN: $1809-1261$

UNIEURO, Brasília, número 13, 2014, pp. 159-201.

mudança nos padrões de gastos, disposição e planejamentos militares" (ADLER; BARNETT, 1998, p. 52).

Na segunda fase as interações são intensificadas, novas organizações e instituições são criadas e surgem identidades coletivas que incentivam expectativas de mudanças pacíficas entre os membros da comunidade. Indicadores de confiança mútua podem ser vistos na esfera militar quando, por exemplo, as aquisições de armamentos refletem posturas militares interdependentes e há intercambio de informações de inteligência (ADLER; BARNETT, 1998).

Por fim, na fase madura, existe uma identidade compartilhada e a comunidade de segurança consolida-se com o preceito fundamental de expectativas confiáveis de mudanças pacíficas entre seus membros. Os indicadores válidos para esta fase estão vinculados ao tipo de comunidade de segurança pluralista. Para as parcialmente integradas considera-se: multilateralismo, fronteiras não fortificadas, mudanças no planejamento militar, definição comum de ameaça e discurso e linguagem comunitária. Para as estreitamente integradas, além destes, considera-se: segurança cooperativa e coletiva, alto nível de integração militar, coordenação política contra ameaças "internas", livre movimento de população, internacionalização da autoridade e polis "multiperspectivada", ou seja, as regras são compartilhadas a nível nacional, transnacional e supranacional (ADLER; BARNETT, 1998).

Segundo Kacowicz (1998), uma comunidade de segurança pluralista é a mais elevada forma de zona de paz, marcada pela existência de normas e valores comuns, instituições políticas, identidades comuns e interdependência profunda. "Não é idealista conceber a possibilidade de que um conjunto de Estados renuncie ao uso da violência entre si" (MAGALHÃES, 2012, p. 82). Deutsch, o pioneiro no estudo das comunidades de segurança, acreditava que o seu trabalho era uma contribuição para o estudo de possíveis caminhos para o homem abolir a guerra. Décadas depois, Adler e Barnett retomaram o conceito de Deutsch, desenvolvendo um método de análise próprio, afirmando 


\section{Artigo original}

Hegemonia - Revista Eletrônica de Relações Internacionais do Centro Universitário Unieuro

ISSN: $1809-1261$

UNIEURO, Brasília, número 13, 2014, pp. 159-201.

que não só acreditavam que uma comunidade existe em nível internacional, como também que os Estados que a compõe poderiam desenvolver disposições pacíficas.

Segundo Nathan (2004), no entanto, a literatura sobre comunidade de segurança, especificamente Adler e Barnett, tem negligenciado uma questão fundamental: a instabilidade interna. A partir dos seus estudos sobre a África, ela concluiu que "a estabilidade interna, definida como a ausência de violência em grande escala em um país, é uma condição necessária de uma comunidade de segurança" (NATHAN, 2004, p.1). Segundo Nathan (2004, p. 3), "a violência doméstica em larga-escala impede a realização de comunidades de segurança porque torna as pessoas e os Estados inseguros, gera incerteza, tensão e desconfiança entre os Estados, e cria o risco de violência transfronteiriça".

No contexto sul-americano a instabilidade interna é uma variável importante nos estudos de segurança. $O$ fato de a região ser considerada pacífica devido ao baixo número de guerra entre os Estados, principalmente a partir do século $X X$, não significa a ausência de guerras civis e crises internas. A violência na Colômbia é um exemplo. Segundo Buzan (2003) essa é uma guerra de quatro lados envolvendo: guerrilheiros de esquerda, grupos paramilitares de "auto-ajuda", o negócio das drogas e o Estado. "Visto de dentro esses problemas se fundem em um enfraquecimento geral do Estado e privatização da violência" (BUZAN, p. 328, 2003). Disputas militarizadas e crises são incosistentes com uma Zona de Paz. (HOLSTI, 1996). Dessa forma, o entendimento do significado do Conselho de Defesa Sul-Americano para as dinâmicas de segurança do complexo regional sul-americano e as contribuições para uma possível comunidade de segurança na região perpassa não somente pelo nível de relações interestatais como também pelas realidades domésticas de cada agente. Afinal, como afirmam Flemes, Nolte e Whener (2011, p. 113), "sem agente não existe comunidade de segurança". 
Artigo original

Hegemonia - Revista Eletrônica de Relações Internacionais do Centro

Universitário Unieuro

ISSN: $1809-1261$

UNIEURO, Brasília, número 13, 2014, pp. 159-201.

2 A AMÉRICA DO SUL E AS DINÂMICAS DE SEGURANÇA REGIONAL PRECEDENTES A CRIAÇÃO DO CONSELHO DE DEFESA

Com um padrão próprio de comportamento e características particulares, a América do Sul tornou-se um desafio para os estudos de segurança regional que buscaram compreender como a região manteve a baixa eminência de guerras interestatais, principalmente a partir do século $X X$, mesmo em condições adversas. As mudanças pacíficas aqueceram as discussões em torno da consolidação da região como uma zona de paz ou comunidade de segurança. Para compreender tais mudanças, entretanto, é necessário um olhar crítico para a história da região, percebendo-a como resultado de um longo processo de construção social que, como afirmou Hurrel (1998), oferece fundamentos relevantes para duvidarmos de que anarquias regionais são iguais em qualquer lugar.

Segundo Buzan e Wæver (2003), a história pós-independência é a chave para entender a América do Sul no presente, pois, ainda que esse processo possa não ter acionado imediatamente grandes guerras, ele levou a fronteiras instáveis e contestadas. "A soberania territorial tem sido historicamente a maior fonte de guerras domésticas e internacionais" (HOLSTI, 1996, p. 153). Na América do Sul, principalmente durante o século XIX, os territórios eram constantemente reclamados. Durante esse período seis guerras foram formalmente declaradas, dentre elas a Guerra do Paraguai (1865-1870) e a Guerra do Pacífico (1879-1884), ocorreram diversas intervenções, invasões armadas e disputas militarizadas. Teóricos como Holsti classificaram a região como uma típica Zona de Guerra. "Desde o final do século XIX, em contraste, a América do Sul tem sido uma Zona sem guerra caracterizada pela mudança pacífica, resolução pacífica de controvérsias e somente infrequentes intervenções" (HOLSTI, 1996, p. 156).

As explicações a respeito das causas desta mudança, no entanto, não 


\section{Artigo original}

Hegemonia - Revista Eletrônica de Relações Internacionais do Centro Universitário Unieuro

ISSN: $1809-1261$

UNIEURO, Brasília, número 13, 2014, pp. 159-201.

são unívocas. O papel da democratização, grandes distâncias geográficas, pouca infra-estrutura e integração interna, papel estabilizador dos Estados Unidos, equilíbrios de poder e dissuasão, Brasil como estabilizador hegemônico optando pela solução de controvérsias pela via diplomática, forças armadas fracas e esforços destinados em primeiro plano a resolver problemas de ordem interna, além dos valores e história comum, são apontados como alguns dos possíveis fatores. Optar por uma única explicação dificilmente seria o melhor caminho, principalmente considerando, como afirma Holsti (1996), que a região é um distinto sistema internacional que, ainda que ligado a outros sistemas, preserva características e dinâmicas próprias.

Segundo Buzan e Wæver (2003), a evolução de formação de conflito para uma zona sem guerra com reconhecidos avanços a uma zona de paz, no entanto, não é uma característica que corresponde à região como um todo, mas sim ao subcomplexo Cone Sul. Isto porque, segundo os autores, o complexo regional de segurança da América do Sul seria composto por dois subcomplexos, o Norte Andino e o Cone Sul, com dois núcleos distintos, a questão das drogas na Colômbia e o futuro do Mercosul.

No Cone Sul três desenvolvimentos chaves transformaram uma formação de conflito que perdurou durante um longo período em algo próximo a uma comunidade de segurança. Primeiro, a aproximação entre Brasil e Argentina desenvolvendo uma cooperação econômica, que culminou na criação do Mercosul, e uma cooperação na área nuclear, mudando o padrão de amizade e inimizade na região e resultando em uma mudança estrutural do subcomplexo. Segundo, a integração regional no Mercosul. Por fim, a resolução de uma parte significativa dos conflitos transfronteiriços entre os países da região. No complexo Norte Andino, formado pelo Peru, Equador, Venezuela, Colômbia e Guiana, entretanto, as dinâmicas de rivalidade e hipóteses de conflito não teriam sido superados, mas sim agravados com o problema das drogas (BUZAN; WÆVER; 2003).

O problema transnacional das drogas envolve uma dinâmica ampla e 


\section{Artigo original}

Hegemonia - Revista Eletrônica de Relações Internacionais do Centro Universitário Unieuro

ISSN: $1809-1261$

UNIEURO, Brasília, número 13, 2014, pp. 159-201.

complexa, e Buzan e Wæver reconheciam, ainda no início da década de 2000, que ele poderia eventualmente se tornar um laço que uniria toda a região, ainda que naquele momento significasse "o principal divisor da América do Sul em duas metades" (2003, p. 336). Para os autores, embora houvesse características bastante distintas que resultava em reconhecer dois subcomplexos na região, o Brasil era um elemento central que mantinha a América do Sul como um único CRS, sendo um país fundamental no Cone Sul, mas também com interesses no Norte Andino, preocupando-se com a questão das drogas, a intervenção dos EUA na região e a Amazônia (BUZAN; WÆVER; 2003).

O Brasil tem definido seu entorno regional como prioridade da sua política externa e buscado consolidar a ideia de unidade sul-americana. Parte dos principais projetos de integração da região, o país rejeita a imagem de potência regional hegemônica e alimenta a premissa de que os problemas da região devem ser resolvidos pelos Estados que a compõe, ou seja, sem a intervenção de potências externas. Em relação à questão das drogas na Colômbia, o Brasil sustentou um posicionamento crítico quanto à militarização do problema a partir do Plano Colômbia, através do qual os Estados Unidos destinaram bilhões de ajuda financeira, dos quais grande parte foram investidos na modernização e reforço do armamento militar da Colômbia.

A América Latina é uma região estratégica para os Estados Unidos. No que se refere ao Norte Andino, o interesse do país na região está relacionado, dentre outros aspectos, as fontes energéticas provenientes da região e garantir as importações de petróleo advindas do Equador e da Colômbia (BANDEIRA, 2009). Na Colômbia, grande parte das empresas que extraem petróleo é norteamericana e os cinco oleodutos existentes no país, sobretudo o que transporta de Arauca para o Caribe, sofrem anualmente mais de uma centena de ataque e sabotagem das FARC e do ELN (BANDEIRA, 2009).

Ainda que não seja um Estado-parte e que a região tenha uma dinâmica de segurança própria, os Estados Unidos tem um papel relevante no CRS da 


\section{Artigo original}

Hegemonia - Revista Eletrônica de Relações Internacionais do Centro Universitário Unieuro

ISSN: $1809-1261$

UNIEURO, Brasília, número 13, 2014, pp. 159-201.

América do Sul. "A relação é marcada por penetração e não sobreposição" (BUZAN; WÆVER; 2003). Para Hurrel (1998), a presença do país na região é um dos elementos que, juntamente com os conflitos transfronteiriços ainda não solucionados e a questão das guerras civis e violência social, dificultam a noção de uma comunidade de segurança na região.

No sentido proposto por Deutsch, de que em uma comunidade de segurança "Há uma garantia real de que os membros dessa comunidade não lutarão uns com os outros fisicamente, mas resolverão suas disputas de alguma outra forma" (1957, p. 2), Hurrel (1998, p. 270) acredita que não é impossível se "esconder atrás da distinção entre guerras internacionais e outras formas de conflitos sociais". Embora possa ser que não esteja clara a relação entres esses dois, os altos índices de conflitos sociais e privatização da violência fornecem mais uma razão para duvidar da existência de uma comunidade de segurança (HURREL, 1998). Ainda assim, o autor acredita que é possível perceber uma comunidade de segurança, mesmo que limitada, no âmbito do Mercosul, construída em torno das mudanças no núcleo da relação entre tradicionais rivais da região: Brasil e Argentina.

De fato, durante um longo período da história da região, as relações entre Brasil e Argentina foram marcadas por desconfianças mútuas e pela lógica da rivalidade que alcançava diversas esferas, como, a econômica, a militar e até mesmo o desenvolvimento de tecnologia nuclear. Durante a década de 1970 um momento de grande tensão envolveu a controvérsia em torno de Itaipu. Até então, hipóteses de conflitos eram reais nas percepções dos dois Estados. Porém, ainda durante a década de 1970, pela via diplomática, as questões envolvendo Itaipu foram solucionadas e, em 1980, foi celebrado o primeiro acordo na área nuclear. Desde então, os dois países aprofundaram a cooperação bilateral e a integração na área econômica e nuclear, de tal modo, que as hipóteses de conflito tornaram-se obsoletas, possibilitando a criação de um dos principais projetos de integração da região: o Mercosul. No discurso de 10 anos de comemoração da criação da Agência 
Artigo original

Hegemonia - Revista Eletrônica de Relações Internacionais do Centro

Universitário Unieuro

ISSN: $1809-1261$

UNIEURO, Brasília, número 13, 2014, pp. 159-201.

Brasileiro-Argentina de Contabilidade e Controle de Materiais Nucleares (ABACC), o professor Celso Lafer afirmou que "A aproximação Brasil-Argentina inverteu o signo das relações bilaterais, que deixaram de constituir fator de incertezas para o equilíbrio estratégico da América do Sul e passaram a ser ao contrário, uma garantia de paz e estabilidade para a região".

Além das mudanças pacíficas no relacionamento entre Brasil e Argentina, as relações bilaterais Chile-Argentina, que também protagonizaram momentos de grandes tensões relacionados às disputas no Canal de Beagle, deram um grande salto qualitativo por meio de diversos acordos diplomáticos. Ainda em 1995, os dois países assinaram um Memorando de Entendimento para o Fortalecimento da Cooperação em Matéria de Segurança e, em 2006, criaram a Força Militar Conjunta Cruz del Sur. Segundo Rivera (2011, p. 481), a Cruz del Sur pode constituir um "antecedente para uma futura força que tenha como base ao Mercosul. Também pode representar uma relevante oportunidade para aprofundar a integração e reforçar o objetivo comum dos países de alcançar sua plena e integral inserção nas correntes políticas globais". Rivera, assim como Flemes (2004), argumenta a existência de uma Comunidade de Segurança na região envolvendo Argentina, Chile e Brasil. Segundo este autor, um importante avanço nessa direção foi a Declaração Política do Mercosul, Bolívia e Chile como uma Zona de Paz.

No entanto, ainda que reconhecidas as mudanças pacíficas que ocorreram na América do Sul com o incremento nas relações bilaterais e dissolução de hipóteses de conflito entre alguns atores da região, mesmo para aqueles que afirmam a existência de uma comunidade de segurança na América do Sul, existem limites, não apenas em relação à profundidade da integração mas também quanto aos Estados que fazem parte do processo. Não se pode falar que a América do Sul é uma Zona de Paz consolidada, ainda que se reconheça o significativo incremento nas relações bilaterais de alguns países. Dentre os motivos, está o que Buzan e Wæver consideravam o núcleo do subcomplexo Norte Andino e o divisor da região em duas metades, a 


\section{Artigo original}

Hegemonia - Revista Eletrônica de Relações Internacionais do Centro Universitário Unieuro

ISSN: $1809-1261$

UNIEURO, Brasília, número 13, 2014, pp. 159-201.

questão das drogas na Colômbia. Segundo os autores, o complexo sulamericano não seria integrado em torno de um projeto integrador, ainda que as variáveis e os processos de securitização tivessem raízes independentes que se unem quando se desenvolvem (BUZAN; W/EVER; 2003).

Em 2008, no âmbito da UNASUL, foi criado o Conselho de Defesa SulAmericano, "uma iniciativa inovadora de cooperação militar na América do Sul" (ABDUL-HAK, 2013, p. 19). Envolvendo os doze países da região, o conselho é uma instância de consulta, cooperação e coordenação em matéria de defesa e define como um dos seus objetivos centrais a consolidação da região como uma Zona de Paz. Segundo Pagliari (2011), assim como a UNASUL, o CDS constitui-se como um esforço da região para produzir consensos e intitucionalizar a aproximação regional, de modo que ela possa tratar dos seus problemas sem a participação dos Estados Unidos. Como afirma Saint-Pierre "A ameaça só se constitui e opera na percepção daquele que é ameaçado". (grifo do autor) (2010, p. 34). Ou seja, ela envolve um processo de interpretação de cada ator. A América do Sul, como afirmado até então, é uma região que dispõe de características e dinâmicas próprias, ainda que possa sofrer a interferência de potências externas. A criação do CDS cria expectativas e possibilidades de mudanças no Complexo Regional de Segurança sulamericano.

3 O CONSELHO DE DEFESA SUL-AMERICANO E SUAS IMPLICAÇÕES NO CONTEXTO DE SEGURANÇA REGIONAL

O Conselho de Defesa Sul-Americano constituído em 2008 no âmbito da UNASUL, a partir de uma proposta brasileira, é um orgão inovador por gerar um ambiente privilegiado para o diálogo em matéria de defesa e promover a cooperação entre os doze países da região. Proposto como um órgão de consulta, cooperação e coordenação em matéria de defesa, o Conselho refletiu, 


\section{Artigo original}

Hegemonia - Revista Eletrônica de Relações Internacionais do Centro Universitário Unieuro

ISSN: $1809-1261$

UNIEURO, Brasília, número 13, 2014, pp. 159-201.

desde o seu processo negociador, as diferentes percepções de segurança e defesa entre os países da região e o seu caráter consensual.

A proposta para criação do CDS foi, em geral, bem aceita na região, sendo a Colômbia o único país que se opôs, considerando que havia pouco que um novo foro de defesa poderia fazer, para além do trabalho desenvolvido pela OEA; pouca cooperação regional em relação ao combate as FARC e que persistiam algumas resistências ideológicas ao modelo econômico liberal praticado por seu país (ABDUL-HAK, 2013). Posteriormente, entretanto, o presidente Álvaro Uribe decidiu fazer parte do CDS, desde que, as decisões fossem obtidas por meio do consenso, o órgão reconhecesse apenas as forças institucionais consagradas pelas Constituições dos Estados-membros e se rechaçasse formalmente grupos violentos, qualquer que fosse sua origem (PAGLIARI, 2010).

Desde o fim do século XIX e principalmente a partir do século $X X$, a região sul-americana têm sido marcada pela baixa incidência de guerras interestatais, superação de hipóteses de conflitos e tradicionais rivalidades e resoluções pacíficas de controvérsias. Entretanto, não é possível afirmar, ainda que diante desse quadro, que as tradicionais ameaças deixaram de existir nas percepções dos atores da região, principalmente no contexto andino. Exemplo disto foi a crise entre Equador e Colômbia devido a chamada Operação Fênix, onde a Colômbia violou o espaço aéreo equatoriano ao atacar o acampamento das FARC em Angostura. Para o embaixador Pinta Gama (2010, p. 352), este ato, além de significar "o estopim de nova crise política com contornos militares nos Andes, inaugurava a doutrina do ataque preventivo na América do Sul, aprofundando as diferenças políticas e ideológicas entre Colômbia maior aliado dos Estados Unidos da América na região - e seus vizinhos andinos". Como a percepção de ameaça é definida por cada ator, as reações em cadeia da violação da soberanial territorial do Equador gerou não apenas reações por parte deste Estado mas também por parte de outros países da região, como a Venezuela. 


\section{Artigo original}

Hegemonia - Revista Eletrônica de Relações Internacionais do Centro Universitário Unieuro

ISSN: $1809-1261$

UNIEURO, Brasília, número 13, 2014, pp. 159-201.

$\mathrm{O}$ ataque colombiano, não ao Equador, mas violando sua soberania territorial, levou o governo venezuelano a securitizar aquele país rompendo relações diplomáticas, fechando fronteiras bilaterais e deslocando tropas. As tensões envolvendo os três Estados foram discutidas em uma sessão extraordinária do Conselho Permanente da OEA, onde a Colômbia reconheceu a violação territorial, porém, questionou supostos vínculos do Equador e da Venezuela com as FARC (ABDUL-HAK, 2013). Embora a adoção de uma Resolução que "reconheceu a violação da soberania e da integridade territorial do Equador e dos princípios do Direito Internacional", os Estados Unidos emitiram no dia seguinte "uma declaração própria em que se dissociavam do consenso" (ABDUL-HAK, 2013, p. 145).

$O$ incidente de Angostura reforçou a percepção quanto as limitações de organismos regionais, como a OEA, em relação as questões de segurança da América do Sul. Segundo o embaixador Pinta Gama (2010), as dificuldades da organização em relação a promoção do diálogo e do entendimento entre os países do continente americano não chegam a surpreender. Fatores como as crises políticas na região e as divergências dos membros quanto a Cuba reforçam a perspectiva que "a OEA não conseguiu se desvencilhar de conceitos pertencentes a lógica da Guerra Fria". Ademais, "a organização vem perdendo relevância em face de novas geografias de poder nas Américas" (GAMA, 2010, p. 356).

Nesse contexto, os países sul-americanos decidiram criar, no âmbito da UNASUL, um órgão que tratasse os aspectos relativos a defesa. A ideia promovida pelo Brasil não era criar uma aliança militar ou um Conselho de Segurança, mas sim um ambiente privilegiado de discussão que contribuisse para a promoção da confiança mútua e estabilidade regional. Criou-se então, um grupo de trabalho que seria responsável pelo Estatuto do futuro órgão. Ainda que houvesse e ainda haja na região percepções diferentes dos países em termos de defesa e segurança, foi possível chegar a um consenso.

O Estatuto do Conselho de Defesa Sul-Americano da UNASUL reafirma 


\section{Artigo original}

Hegemonia - Revista Eletrônica de Relações Internacionais do Centro Universitário Unieuro

ISSN: $1809-1261$

UNIEURO, Brasília, número 13, 2014, pp. 159-201.

princípios tradicionais como o respeito a soberania, as instituições democráticas, aos direitos humanos, a convivência pacífica entre os povos, a solução pacífica de controvérsias, além dos princípios de gradualidade e flexibilidade presentes no desenvolvimento institucional da UNASUL, entendendo que a integração é um processo que reúne atores, cujas características e percepções são distintas. O Estatuto define também no seu artigo $4^{\circ}$ que os objetivos gerais do CDS são: consolidar América do Sul como uma zona de paz, base para a estabilidade democrática e o desenvolvimento integral de nossos povos, e como contribuição para a paz mundial; construir uma identidade sul-americana em matéria de defesa, que leve em conta as características sub-regionais e nacionais e que contribua para o fortalecimento da unidade da América Latina e o Caribe e gerar consensos para fortalecer a cooperação regional em matéria de defesa.

Segundo Abdul-Hak, a criação do Conselho de Defesa "decorreu de uma reavaliação da forma de engajamento estratégico da América do Sul com outros complexos regionais no Hemisfério e, em particular, com a principal potência militar regional e mundial, os EUA" (2013, p. 155). Para Saint-Pierre (2010, p. 19), "tanto las percepciones compartidas como las amenazas y desafíos subregionales justifican un mecanismo específico para la defensa que permita reforzar, antecipar o intensificar los instrumentos hemisféricos que se mostraron inadecuados, morosos, omisos ó inútiles". Dentre eles, o Tratado Interamericano de Assistência Recíproca (TIAR) assinado em 1947. Esse acordo criava um mecanismo de segurança e defesa coletiva. "A ideia era a formação de uma frente comum em caso de ataque a qualquer membro, invocando o exercício imanente da legítima defesa individual ou coletiva" (PAGLIARI, 2006, p. 29). No entanto, o acordo perdeu relevância e sua credibilidade foi contestada com o apoio dos Estados Unidos ao Reino Unido na Guerra das Malvinas ${ }^{2}$. Considerando que o TIAR tornou-se obsoleto, alguns 


\section{Artigo original}

Hegemonia - Revista Eletrônica de Relações Internacionais do Centro

Universitário Unieuro

ISSN: $1809-1261$

UNIEURO, Brasília, número 13, 2014, pp. 159-201.

países como, México, Venezuela e Colômbia denunciaram o tratado.

Os Estados Unidos, ainda que não faça parte do complexo regional de segurança sul-americano (BUZAN, WÆEVER, 2003), é um ator relevante nas dinâmicas de segurança da região. Enquanto uma potência militar global, alguns países receiam que, utilizando-se de prerrogativas como guerra contra o terrorismo, instabilidade política e preservação dos direitos humanos ele intervenha em seus domínios internos. Em particular, na região sul-americana, as preocupações perpassam pela militarização do combate ao narcotráfico e as guerrilhas através do Plano Colômbia. Nesse sentido, em 2009, um novo acordo de cooperação militar entre Colômbia e Estados Unidos, que envolvia a utilização de sete bases militares colombianas pelos norte-americanos para combater o narcotráfico e a guerrilha, gerou controvérsias entre os países da região, que criticavam a falta de transparência do acordo e pediam garantias de que a utilização das bases servissem apenas ao propósito declarado e que a inviolabilidade territorial dos países da região fosse respeitada.

Em agosto de 2009 foi realizada uma reunião de Chefes de Estado e de Governo em San Carlos de Bariloche para tratar do tema. Durante a reunião o presidente Chávez apresentou um documento denominado "Estratégia SulAmericana. Livro Branco, Comando de Mobilidade Aérea (AMC)" formulado pela Força Aérea dos Estados Unidos, o qual revelava que a partir da base de Palanquero, aéronaves específicas poderiam atingir qualquer parte da América do Sul. Segundo o embaixador Pinta Gama (2010), porém, o documento não esclarecia em que medida este fator contribuiria para a consecução do propósito de combater atividades ilícitas na região, contribuindo para fomentar as desconfianças. A Colômbia defendia-se argumentado que, embora os países da região se mostrassem solidários com o problema enfrentado pelo país nas soberania plena nestes territórios e insiste no diálogo com a Grã-Bretanha, tem recorrido a organismos internacionais e exposto a relutância britânica ao diálogo. Segundo o Ministerio de Defensa da Argentina (2014) "La recuperación de dichos territorios y el ejercicio pleno de la soberanía, respetando el modo de vida de sus habitantes y conforme a los principios del derecho internacional, constituyen un objetivo permanente e irrenunciable del pueblo argentino". 


\section{Artigo original}

Hegemonia - Revista Eletrônica de Relações Internacionais do Centro Universitário Unieuro

ISSN: $1809-1261$

UNIEURO, Brasília, número 13, 2014, pp. 159-201.

últimas décadas, somente os Estados Unidos contribuiu com recursos humanos e militares, e propôs que fosse adotado um novo enfoque no combate do problema das drogas, baseado na corresponsabilidade, pois a região não seria apenas produtora e rota de trânsito das drogas, mas também consumidora (ABDUL-HAK, 2013).

Segundo Pinta Gama, "Talvez por falta de opção, a Declaração de Bariloche inaugurou certa confusão conceitual entre defesa, domínio essencial de atuação do CDS, e segurança, vocábulo sequer mencionado em seu Estatuto" (2010, p. 354). A Declaração Presidencial, além de reafirmar princípios tradicionais como a manutenção da região como uma zona de paz e a inviolabilidade territorial dos países, instruiu os Ministros de Relações Exteriores e da Defesa a desenvolverem medidas de fomento da confiança no âmbito da segurança e defesa (MFC), incluindo áreas como, verificação e garantias para acordo de defesa e de combate ao tráfico de armas, narcotráfico e terrorismo.

Dessa forma, de acordo ao mandato presidencial, ocorreram duas reuniões de Ministros de Defesa e Relações Exteriores. Na primeira não obtevese um consenso quanto a execução do mandato, ainda que houvesse consenso em torno de algumas medidas como: a notificação de acordos militares assinados pelos Estados-membros e o intercâmbio de informações sobre efetivos, armas, equipamentos e gastos militares. Na segunda, os Ministros chegaram a um consenso em torno de temas como intercâmbio de informações e aumento de transparência sobre sistemas de defesa nacionais; notificação de atividades militares; cooperação em temas de segurança e compromissos relacionados a proibição do uso da força e qualquer ameaça a estabilidade. Os Ministros indicaram ainda que as medidas acordadas seriam executadas pelo CDS, pelo Conselho de Ministros de Relações Exteriores e por um futuro órgão da UNASUL sobre o combate ao narcotráfico de acordo com suas respectivas competências (GAMA, 2010). Isso reflete uma preocupação exposta, desde a proposta inicial do Conselho de Defesa, quanto a distinção 


\section{Artigo original}

Hegemonia - Revista Eletrônica de Relações Internacionais do Centro Universitário Unieuro

ISSN: $1809-1261$

UNIEURO, Brasília, número 13, 2014, pp. 159-201.

entre segurança e defesa, cabendo a este Conselho somente a última instância.

As MFC, negociadas durante 2010, foram aprovadas na Reunião Ministerial do CDS realizada em Guayaquil. Os Ministros da Defesa decidiram submeter os procedimentos acordados no âmbito da segurança - que refletem mais dificuldades para o consenso, na medida em que grande parte dos países da região não conferem competência ao Ministério da Defesa para tratar de temas como tráfico de drogas, diferente da Colômbia, por exemplo - ao Conselho de Ministros de Relações Exteriores, a partir do entendimento que sua esfera delimita-se na temática da defesa (ABDUL-HAK).

As atividades a serem desenvolvidas no âmbito do CDS compõem os Planos de Ação acordados pelos Estados-membros. Dentre os resultados obtidos está a criação do Centro de Estudos Estratégicos do Conselho de Defesa, proposta Argentina presente no Plano de Ação 2010-2011. O CEED localiza-se na Argentina e desenvolve seus trabalhos a partir das determinações do CDS. Dentre suas funções estão: desenvolver estudos e pesquisas na área de defesa e segurança, sempre a pedido do CDS, e estabelecer, por meio dos Ministérios da Defesa, relações institucionais e intercâmbios com os centros estratégicos nacionais dos Estados-membro. Os Ministros da Defesa também aprovaram a criação da Escola de Defesa SulAmericana (ESUDE). Em 2014 foi realizada a primeira reunião da ESUDE, onde o trabalho das representações nacionais resultou em uma proposta de Estatuto e Regulamentos que será encaminhada à Instância Executiva para apreciação e aprovação. O Vice-Ministro da Defesa do Equador, Carlos Larrea, afirmou que a reunião é "um passo fundamental para o desenvolvimento de uma visão compartilhada da defesa regional, bem como a consolidação do processo de institucionalização da UNASUL e do fortalecimento das ofertas acadêmicas de abordagem regional na matéria" (CEED, 2014).

Dentre as atividades previstas pelo Plano de Ação 2014 destacam-se: a criação de um grupo de trabalho para "Propor e consolidar lineamentos 


\section{Artigo original}

Hegemonia - Revista Eletrônica de Relações Internacionais do Centro Universitário Unieuro

ISSN: $1809-1261$

UNIEURO, Brasília, número 13, 2014, pp. 159-201.

estratégicos do CDS-UNASUL, para a construção progressiva e flexível de uma visão compartilhada de defesa regional", definindo interesses gerais e específicos dos Estados membros no âmbito da defesa, com o propósito de analisá-los e compatibilizá-los com os lineamentos estratégicos da visão compartilhada de defesa sul-americana; a realização da capacitação de Técnica Polar para a participação Antártica 2015 e a manutenção do Grupo de Trabalho constituído por especialistas com o propósito de apresentar o desenho, desenvolvimento e produção regional de um sistema de aeronaves não tripuladas (VANT REGIONAL). Além destas atividades, o Plano de Ação prevê a realização de cursos, seminários, e reuniões, que acontecem desde a criação do CDS.

O Conselho de Defesa Sul-Americano constitui-se então como um canal permanente de diálogo para os países da região. Como afirmam Adler e Barnett (1998), as organizações são locais de socialização e aprendizagem que contribuem direta ou indiretamente para a formação de comunidades de segurança a partir das interações, criação de normas de comportamento e mecanismo de controle. Segundo o embaixador Pinta Gama (2010, p. 363), é lícito afirmar que sem o CDS "os recentes desafios à segurança na região andina e as tensões entre a Colômbia e a Venezuela poderiam ter escalado a níveis próximos, talvez, de um conflito armado convencional". Entretanto, reconhecidos os avanços, a consolidação do $\operatorname{CDS}$ e, de forma geral, a consolidação da região como Zona de Paz, ainda enfrenta desafios que perpassam tanto pela dissolução das hipóteses de conflito ainda existentes quanto por estratégias que reforcem a segurança nos países sul-americanos, porquanto o continente seja marcado por altos índices de violência social e, especificamente no caso da Colômbia, pela luta por mais de 40 anos contra o narcotráfico e grupos guerrilheiros.

\subsection{DESAFIOS TRADICIONAIS: AS HIPÓTESES DE CONFLITOS E OS GASTOS}


Artigo original

Hegemonia - Revista Eletrônica de Relações Internacionais do Centro

Universitário Unieuro

ISSN: $1809-1261$

UNIEURO, Brasília, número 13, 2014, pp. 159-201.

MILITARES DA REGIÃO

No contexto das hipóteses de conflitos que ainda existem na região, o aumento dos gastos militares e o tipo de armamento adquirido por alguns países sul-americanos provocaram desconfianças e questionamentos acerca de uma possível corrida armamentista na região, intensificando-se uma demanda por mais transparência. De forma geral, os Estados justificaram tais inversões como necessárias a fim de recuperar um arsenal militar obsoleto, datado de décadas atrás. Ademais, alguns analistas argumentaram que tal aumento acompanha uma tendência mundial e, no caso da região, o aspecto econômico foi decisivo, principalmente pelo aumento dos preços das commodities. Entretanto, ainda que tais argumentos sejam ponderados, é preciso considerar as diferentes percepções dos atores regionais, bem como suas definições de ameaça. Dessa forma, essa análise considera quatro países da região: Venezuela e Chile, pelo volume gasto e pelo tipo de aquisições; Colômbia, pelo contexto interno específico e por destinar mais de $3 \%$ do PIB para gastos militares (maior percentual da região) e Brasil, por sua posição regional e aspirações mundiais, além de ser responsável por mais de $50 \%$ dos gastos militares do subcontinente.

A América do Sul destinou US\$ 65,9 bilhões para gastos militares em 2012 (SIPRI, 2013). Comparado com outras regiões como, América do Norte, Europa e Ásia este valor é considerado relativamente baixo. Porém, analisando-se a realidade regional, percebe-se que o mesmo é resultado de significativos incrementos ao longo dos últimos anos. Com relação a 2011, os gastos militares da região aumentaram 3.8\%. No período de 2008-2012 a Venezuela tornou-se o maior importador de armas convencionais da região e o décimo terceiro maior importador mundial. Ademais, países como, Argentina, Peru, Colômbia e Uruguai também aumentaram seus gastos militares. Por outro lado, o Brasil, responsável por mais da metade dos gastos militares da 


\section{Artigo original}

Hegemonia - Revista Eletrônica de Relações Internacionais do Centro Universitário Unieuro

ISSN: $1809-1261$

UNIEURO, Brasília, número 13, 2014, pp. 159-201.

região e detentor do décimo primeiro maior orçamento de defesa mundial, registrou uma diminuição dos seus gastos militares em 2013.

Na América do Sul, em especial no Cone Sul, as mudanças pacíficas nas relações Brasil-Argentina e Argentina-Chile, marcadas por processos de securitização e protagonistas de momentos de grandes tensões no subcontinente, contribuíram para a construção de uma Zona sem guerra na região. Entretanto, se no Cone Sul as relações entre os Estados evoluíram de tal maneira que se argumenta a existência de uma Comunidade de segurança, na região andina existem antigas hipóteses de conflitos que ainda não foram superadas. Segundo Buzan e Wæver (2003), a região não haveria superado a formação de conflito. Medeiros Filho (2010) afirma que, ainda que as porções (Amazônia, Andes e Cone Sul) que compreendem a América do Sul se sobreponham, é possível dividir a região em dois grandes arcos: "o arco da estabilidade", região que engloba a vertente atlântica e onde os processos de integração desenvolveram-se mais, e o "arco da instabilidade", que corresponde à região dos "Andes" e "Amazônia", onde persistem potenciais conflitos (ver figura 1).

Em uma região onde as hipóteses de conflitos não foram completamente superadas, o aumento dos gastos militares pode ser visto com apreensão por alguns atores. Isso porque, quando um Estado aumenta seus gastos militares isso cria expectativas tanto para ele quanto para os outros. Dependendo destas expectativas, os Estados desenvolvem suas ações e, a partir de então, se inicia todo um processo de "sinalização, interpretação e resposta". Wendt (1992, p. 405) afirma que este "É um mecanismo de reforço; a interação reforça determinadas idéias sobre o outro e faz rechaçar 


\section{Artigo original}

Hegemonia - Revista Eletrônica de Relações Internacionais do Centro Universitário Unieuro

ISSN: $1809-1261$

UNIEURO, Brasília, número 13, 2014, pp. 159-201.

outras". Ainda que não se possa afirmar que a região sul-americana esteja propensa a uma guerra, o aumento significativo dos gastos militares deve ser dimensionado ao passo que as "motivações e as implicações na capacidade militar do outro serão considerados pelos demais Estados" (PAGLIARI; FONTES, 2012, p. 2). Os gastos militares chilenos e venezuelanos, por exemplo, chamam atenção pelo caráter não somente quantitativo mas também qualitativo das aquisições.

Segundo Pagliari e Fontes (2012, p. 4), "Não se pode considerar de outra forma - uma vez que o Chile se coloca em um processo de modernização sem equivalência na sub-região - que o investimento chileno vai além de apenas um processo de substituição de equipamentos defasados". A compreensão dos gastos chilenos demanda uma análise histórica, a partir da qual, percebe-se que destinar grandes quantias para gastos militares no país é uma política de Estado que existe desde suas origens como Nação e que tem sido potencializada nos últimos anos em virtude dos altos preços internacionais do cobre (CALLE, 2010).

No período de 2003-2007 o Chile tornou-se o maior importador de armas convencionais da América do Sul e o décimo segundo maior importador mundial. Para manter o nível elevado das suas aquisições o país contou com pelo menos dois fatores, o bom crescimento econômico e a Lei do Cobre objeto de muitos protestos no sentido da sua eliminação -, que estabelece que $10 \%$ dos ingressos pelas exportações de cobre e pelos seus subprodutos por parte da Codelco, empresa estatal, se destina as Forças Armadas (CALLE, 2010). Existe porém, um consenso básico da elite política chilena, seja sua direita ou sua esquerda, de manter o país entre os maiores investidores em capacidades militares da América Latina (CALLE, 2010).

Com relação as tensões com seus vizinhos sul-americanos, houve recentemente uma reativação das tensões com o Peru em relação a delimitação das fronteiras marítimas. Em 2008, o Presidente peruano Alan García levou a questão a Corte Internacional de Haya. Segundo Calle (2010, 
Artigo original

Hegemonia - Revista Eletrônica de Relações Internacionais do Centro Universitário Unieuro

ISSN: $1809-1261$

UNIEURO, Brasília, número 13, 2014, pp. 159-201.

p.8), "A pocas semanas de la elevación al tribunal internacional, las FF.AA. de Chile con la presencia de la Presidente Bachelet llevaron a cabo una contundente demostración de fuerza en un ejercicio militar conjunto en el Norte de Chile". Em 2014, a Corte Internacional de Justiça declarou sua decisão, atendendo parte das reivindicações do Peru, que recebeu uma região marítima até então controlada pelo Chile. Os presidente Ollanta Humala e Sebástian Piñera já haviam concordado em respeitar a decisão da Corte. 0 Chile também possui litígios fronteiriços com a Bolívia, este, ainda sem solução, resultou em tensões e rupturas diplomáticas. A Bolívia levou a Corte Internacional de Haya uma ação contra o Chile por uma saída soberana para o mar, a qual o país perdeu na Guerra do Pacífico. O Chile declarou que não há diálogo a respeito da soberania marítima do país

$\mathrm{Na}$ América do Sul, assim como os gastos chilenos, os gastos venezuelanos chamam atenção, principalmente pelo tipo de armamento que vem sendo adquirindo. $O$ aumento das importações venezuelanas fez com que o país passasse, em termos mundiais, de $56^{\circ}$ maior importador mundial em 1998-2002, para $24^{\circ}$ em 2003-2007, tornando-se o $13^{\circ}$ maior importador de armas convencionais do mundo em 2008-2012. Dentre os fatores para o incremento, segundo Villa e Viggiano (2012), estão: os vários anos de constante aumento dos preços do petróleo, a vontade política do presidente Chávez para melhorar as capacidades militares do país e para aumentar a posição política na região.

Segundo Calle (2010), no caso venezuelano existe uma complexa combinação entre uma doutrina militar de guerra assimétrica e o tipo de armamento sofisticado para conflitos convencionais que o país vem aquirindo. Com relação a doutrina, a hipótese de conflito que impera é com a Colômbia (amparada militarmente pelos EUA) ou uma agressão direta por parte dos Estados Unidos. Para ambos os casos a resposta proposta por Caracas tem sido a "guerra do povo", cujas características são, dentre outras, a formação de milicias populares que complementem a ação das Forças Armadas e a 


\section{Artigo original}

Hegemonia - Revista Eletrônica de Relações Internacionais do Centro Universitário Unieuro

ISSN: $1809-1261$

UNIEURO, Brasília, número 13, 2014, pp. 159-201. aquisição de armas de baixo custo e alto rendimento. Porém, o que se tem visto nos ultimos anos são aquisições de equipamentos sofisticados e que seriam de pouca utilidade em um combate aberto com o poder militar dos Estados Unidos (CALLE, 2010).

Segundo Solmirano e Perlo-Freeman (2010), enquanto o aumento dos gastos militares colombianos são justificados pelo conflito interno, as aquisições venezuelanas podem ser, em parte, relacionadas com as tensões com o vizinho. Uma série de acontecimentos geraram uma percepção de desconfiança entre os dois Estados, entre eles, a incursão militar colombiana no Equador em 2008 e o anúncio em 2009 de um novo pacto militar colombiano que daria aos Estados Unidos acesso a bases militares em território colombiano, duramente criticado pela Venezuela.

As aquisições venezuelanas foram apontadas pelos Estados Unidos como potencial ameaça a região, salientando que tais compras são excessivas e desproporcionais ao tamanho venezuelano (PAGLIARI; FONTES, 2010). Em 2006, os Estados Unidos impuseram um embargo que impede a Venezuela de importar do país bens e serviços de defesa e certificaram-a sob a Secção $40 \mathrm{~A}$ Arms and Control Act (AECA), como um país que "não está totalmente cooperativo" na luta contra o terrorismo, o que impede qualquer assistência, venda ou financiamento pelos militares americanos ao país em matéria militar (VILLA; VIGGIANO, 2012).

Com relação aos gastos colombianos, o principal deteminante tem origem interna. Já somam-se décadas de lutas contra o tráfico de drogas e grupos guerrilheiros. A Colômbia é o país que destina a maior parte do PIB para gastos militares na América do Sul - 3,3\%. Em 2012 o país destinou mais de US $\$ 12$ bilhões a gastos militares, o segundo maior gasto da região, atrás somente do Brasil (SIPRI, 2013). Os principais mercados de onde provém as importações colombianas são: Estados Unidos, seguido de Espanha e Brasil - a Colômbia é o único país sul-americano que tem em outro país sul-americano um dos seus principais mercados de importação de armas (VILLA; VIGGIANO, 


\section{Artigo original}

Hegemonia - Revista Eletrônica de Relações Internacionais do Centro Universitário Unieuro

ISSN: $1809-1261$

UNIEURO, Brasília, número 13, 2014, pp. 159-201.

2012). Alguns políticos colombianos demonstraram preocupações acerca de uma possível corrida armamentista na região e sua desvantagem em relação as aquisições venezuelanas.

Segundo Villa e Viggiano (2012), uma visão geral da América do Sul em termos de gastos militares totais ou gastos em compras de armas deve, necessariamente, considerar o papel do Brasil devido o aumento da complexidade de sua economia, a importância relativa do seu PIB na região e a maior complexidade dos seus objetivos políticos globais e regionais. O país destinou US\$ 33 bilhões aos gastos militares em 2012, o que representou 1,5 $\%$ do seu PIB. Assim como outros países da região, o Brasil nos últimos anos começou um programa para modernizar e atualizar suas forças armadas. A Estratégia Nacional de Defesa de 2008 anunciou planos para aumentar as capacidades militares do país e dinamizar a sua indústria nacional de defesa, através de uma série de aquisições incluindo transferência de tecnologia.

Em termos de inserção internacional do Brasil, segurança e defesa são elementos relevantes. O país tem buscado uma posição privilegiada no cenário internacional e, para isso, considera importante uma maior participação em organismos internacionais. Exemplo disto é a participação brasileira em Missões de Paz. Segundo Cervo (2008, p. 147), por meio da missão no Haiti a "ação brasileira promove o bem-estar e o desenvolvimento, usa a cooperação técnica e o próprio futebol, incorpora a filosofia política da ONU, mas persegue status internacional e tem no horizonte outros fins, como o próprio Conselho de Segurança".

Com relação aos gastos militares brasileiros, desde 2007 o país tem colocado em evidência a necessidade de maiores incrementos e um respaldo para projetos atrasados como, a construção do submarino nuclear, e para o desenvolvimento da indústria nacional de defesa. Em 2008, os presidentes Lula e Sarkozy assinaram um acordo para avançar na construção de 4 submarinos convencionais "Scorpene" no Brasil e para fabricação de um outro casco para um submarino nuclear, cuja tecnologia nuclear seria desenvolvida pela marinha 


\section{Artigo original}

Hegemonia - Revista Eletrônica de Relações Internacionais do Centro Universitário Unieuro

ISSN: $1809-1261$

UNIEURO, Brasília, número 13, 2014, pp. 159-201.

brasileira. Entre as justificativas expressas pelo ex-Ministro Nelson Jobim para a construção do submarino nuclear, destaca-se a tarefa de proteger as recentes descobertas de reservas de hidrocarbonetos na costa brasileira (CALLE, 2010). Segundo Calle,

Parece existir un sustancial nivel de consenso nacional acerca de la necesidad de reforzar el pilar militar del país, tanto sea para defender las amplias reservas de recursos naturales del país (minerales, petróleo, gas y la misma agua dulce) y también como forma de reforzar la estratégia diplomática y comercial de proyección del país como potencia emergente a nivel global (2010, p. 5).

Entretanto, considerando os dados fornecidos pelo SIPRI referentes ao ano de 2012, o gasto brasileiro ainda é bastante inferior ao gasto de países como India (US\$ 45,7 bilhões), Alemanha (US\$ 46,1 bilhões) e Japão (US\$ 59,2 bilhões) que também pleiteiam um assento permamente no Conselho de Segurança da ONU. Além disso, é importante considerar que significativas parcelas dos gastos militares da América do Sul, inclusive do Brasil, são aplicados com despesas de pessoal.

Com relação à esfera regional, o Brasil, desde o governo de Itamar Franco, mas principalmente no governo Lula, definiu a América do Sul como prioridade da sua política externa. Em termos de segurança, o país tem hesitado em aprofundar o quadro institucional de segurança hemisférica, porém, em relação ao subcontinente, promoveu a iniciativa de criação do Conselho de Defesa Sul-Americano. Segundo Abdul-Hak (2013, p. 206), "A cooperação é o principal instrumento de que dispõe o Brasil para reafirmar a natureza pacífica e defensiva de seu reequipamento militar, compatível com suas novas oportunidades de inserção no sistema internacional". Em longo prazo, o CDS fortalece o desenvolvimento da capacidade dissuasória regional a partir do aprofundamento da cooperação na esfera de defesa que contribui, dentre outros aspectos, para o desenvolvimento tecnológico e para a promoção de maiores ganhos de escala e eficiência dos recursos destinados aos gastos 


\section{Artigo original}

Hegemonia - Revista Eletrônica de Relações Internacionais do Centro Universitário Unieuro

ISSN: $1809-1261$

UNIEURO, Brasília, número 13, 2014, pp. 159-201.

militares (ABDUL-HAK, 2013) que são, como dito anteriormente, limitados. O CDS é relevante também para a criação de uma identidade sul-americana de defesa, pois é um espaço privilegiado para construção e promoção de definições comuns e valores compartilhados contribuindo para o fortalecimento da confiança mútua. Segundo Adler e Barnett (1998), a confiança é anterior a identidade no sentido em que as crenças que um tem sobre o outro são resultado de encontros e experiências que moldam a definição cultural de ameaça. As instituições contribuem não somente para o aumento das transações como também para a qualidade, e esses processos são essenciais para o desenvolvimento de uma comunidade de segurança (ADLER; BARNETT, 1998).

De forma geral, diversos fatores são apontados para justificar o incremento dos gastos militares da América do Sul. Dentre eles, o crescimento econômico, o aumento do preço das commodities, a necessidade de modernização das Forças Armadas e as percepções, interesses e conjunturas de cada Estado. Ainda que não exista "um risco real e iminente de agressão militar por parte de um Estado abertamente beligerante e expansionista" (ABDUL-HAK, 2013, p. 185), uma maior transparência dos gastos militares dos países da região contribui para a dissolução de desconfianças e favorece a integração regional, na medida em que promovem e reforçam a confiança mútua. Nesse sentido, a Argentina adotou com o Chile um sistema de homologação dos seus gastos de defesa, utilizando também um mecanismo semelhante de medição de gastos com o Peru. Segundo Flemes (2011, p.110) "Este mecanismo incluye [...] la eliminación de cualquier hipótesis de conflicto entre las respectivas doctrinas nacionales de defensa". Em 2010, o CDS se comprometeu a desenvolver um mecanismo de medição de gastos nacionais de defesa.

O Registo Sul-Americano de Gastos de Defesa é parte das medidas de confiança mútua e do Plano de Ação 2010-2011 e sustenta-se na definição comum de gastos de defesa e uma metodologia padronizada para 


\section{Artigo original}

Hegemonia - Revista Eletrônica de Relações Internacionais do Centro Universitário Unieuro

ISSN: $1809-1261$

UNIEURO, Brasília, número 13, 2014, pp. 159-201.

apresentação anual da informação ao CEED, instância técnica responsável pela recepção, consolidação, publicação, análise e arquivo da informação remetida (CEED, 2014). Em 2012, como parte da VI Reunião de Ministros de Defesa do CDS, foi apresentado o "Registro Sul-Americano de Gastos de Defesa" correspondente ao período 2006-2010, que abordava as principais questões sobre os gastos de defesa regional e indicadores individuais, considerando a situação de cada país, além de apresentar um conjunto de conclusões, recomendações gerais e técnicas para a metodologia (CEED, 2014).

\subsection{FATORES DE INSTABILIDADE: O NARCOTRÁFICO E A VIOLÊNCIA SOCIAL}

A América do Sul têm sido caracterizada como uma das regiões mais pacíficas do mundo em termo de guerras interestatais. Desde 1941, sem a eclosão de guerras entre os Estados sul-americanos, a região tem logrado alguns avanços em direção a uma Zona de Paz. Por outro lado, os números de homicídios registrados na região tornam-na uma das mais violentas do mundo (ver figura 2), o que destoa do propósito de uma Zona de Paz ou uma Comunidade de Segurança. Nesse contexto, segundo Medeiros Filho (2010, p. 92), "os problemas principais que envolvem os países da região não seriam "de" fronteira (questão de defesa), mas estariam "na" fronteira (questão de segurança) (grifo do autor).

Figura 2: Índices de homicídios por regiões (para cada 100.000 hab)

O Conselho de Defesa Sul-Americano, desde a sua criação, tem diferenciado defesa (seu objeto) e segurança. A percepção de alguns Estados 


\section{Artigo original}

Hegemonia - Revista Eletrônica de Relações Internacionais do Centro Universitário Unieuro

ISSN: $1809-1261$

UNIEURO, Brasília, número 13, 2014, pp. 159-201.

da região é de que temas de segurança pública não fazem parte das atribuições dos seus Ministérios da Defesa. Dessa forma, defendem que "O equacionamento definitivo da crise da violência e criminalidade das sociedades sul-americanas não ocorreria por meio da repressão militar, mas pelo aprofundamento da democracia e o fortalecimento das suas principais instituições civis" (ABDUL-HAK, 2013, p. 215).

Segundo Abdul-Hak (2013), no entanto, para outros países da região esta percepção é distinta. De forma geral, segundo a autora, nos países andinos e na Bolívia, com intensidades distintas, a redemocratização e as reformas neoliberais criaram uma tendência a deslegitimação dos regimes democráticos liberal-representativos. Os críticos argumentam uma progressiva erosão dos equilíbrios de poderes a partir de sucessivas reformas constitucionais que reforçam o poder nas mãos do executivo (ABDUL-HAK, 2013). Em particular, a militarização do combate ao narcotráfico na Colômbia, além de evidenciar as diferentes interpretações quanto à relação entre defesa e segurança pública, gerou discussões e reações contrárias a presença militar de uma potência extra-regional na América do Sul.

O "Relatório do Centro de Estudos Estratégicos de Defesa do Conselho de Defesa Sul-Americano a respeito do Crime Organizado Transnacional e Outras Novas Ameaças para a Segurança Regional" (2012) afirma que, frente aos incrementos das ameaças a segurança pública, evidencia-se que os Estados não podem enfrentar sozinhos os delitos que transbordam as fronteiras nacionais. Dessa forma, recomendava-se a criação de um órgão que abordasse a temática de segurança pública de maneira geral ou que houvesse algumas transformações no Conselho que trata do problema mundial das drogas.

Em 2012 foi criado o Conselho Sul-Americano em Matéria de Segurança Cidadã, Justiça e Coordenação de Ações contra a Delinquência Organizada Transnacional. Estabelecido como um órgão de consulta, coordenação e cooperação, o Conselho estabelece, dentre seus objetivos, de acordo com seu Estatuto, promover estratégias, planos de ação e mecanismos de coordenação, 


\section{Artigo original}

Hegemonia - Revista Eletrônica de Relações Internacionais do Centro Universitário Unieuro

ISSN: $1809-1261$

UNIEURO, Brasília, número 13, 2014, pp. 159-201.

cooperação e assistência técnica na sua área de atuação; promover a participação de atores sociais e da cidadania na elaboração dos planos e políticas de segurança cidadã e promover o fortalecimento das instituições governamentais encarregadas da segurança cidadã, justiça e ação contra a delinquência organizada transnacional. A continuidade da cooperação no âmbito desse Conselho e o desenvolvimento de atividades conjuntas com o Conselho sobre o Problema Mundial das Drogas, o que é previsto, é um esforço importante para solucionar graves problemas que afetam a região.

Ainda que produza impactos diferentes dependendo do contexto de cada Estado, dentre os delitos associados ao crime organizado transnacional está o narcotráfico, o terrorismo e as ações de grupos armados fora da lei. Os elevados números de homicídios nos países sul-americanos fortalecem a perspectiva de que, consideradas as particularidades de cada país, os problemas de segurança pública afetam significativamente a região e a cooperação oferece possibilidades para construir soluções conjuntas (ver gráfico 1). Buzan e Wæver (2003), afirmavam que a questão das drogas na Colômbia poderia se tornar um laço que uniria toda a região. Com a intensificação da globalização e a atuação em rede dos problemas transnacionais, o narcotráfico e os outros delitos transbordam para além das fronteiras nacionais, dos subcomplexos regionais ou dos arcos de estabilidade e instabilidade da região.

Gráfico 1: Número de Homicídios por país na América do Sul (2012)*

A cooperação e, de maneira mais profunda, a integração regional contribuem para criar soluções para problemas comuns. Segundo Saint-Pierre (2009, p. 19), "los acuerdos y consensos sobre las cuestiones políticas, entre ellas y principalmente las relativas a defensa, no constituyen el techo de la 


\section{Artigo original}

Hegemonia - Revista Eletrônica de Relações Internacionais do Centro Universitário Unieuro

ISSN: $1809-1261$

UNIEURO, Brasília, número 13, 2014, pp. 159-201.

integración, sino los cimientos y vigas que le harán perdurar". O Conselho de Defesa Sul-Americano é um instrumento promotor da confiança mútua que é um elemento essencial para o aprofundamento da integração regional e para a manutenção da paz no cenário internacional.

\section{CONSIDERAÇÕES FINAIS}

A América do Sul têm sido caracterizada pelos estudos que versam sobre guerra e paz como uma região relativamente pacífica. Desde 1941, o subcontinente não foi palco de guerras entre seus Estados. Essa baixa propensão a guerras interestatais, somada as mudanças pacíficas nas relações Brasil-Argentina e Chile-Argentina, soluções pacífica de controvérsias e a criação de organismos de integração regional levaram alguns autores a acreditar na emergência de uma comunidade de segurança no Cone Sul. Porém, a persistência de hipóteses de conflitos na região andina e as "novas" ameaças, como, o narcotráfico, além do alto índice de violência, são fatores que não somente impossibilitam a consolidação da região como uma zona de paz, como também geram incertezas quanto à obtenção deste fim futuramente.

Nesse cenário, a criação do Conselho de Defesa Sul-Americano é um passo significativo para o fortalecimento da confiança mútua entre os Estados da região, configurando-se como um projeto inovador ao criar um canal de diálogo permanente para tais países discutirem uma área sensível sem a presença de potências extra-regionais. Isto assume particular relevância para um complexo regional que sofre penetração dos Estados Unidos. Se por um lado a região desenvolveu características e dinâmicas próprias ao longo do tempo, por outro a presença dos Estados Unidos gera desconfianças e aprofunda as diferenças. Exemplo disto é o Plano Colômbia. A definição de ameaça é resultado das percepções de cada ator a partir das quais formularão 


\section{Artigo original}

Hegemonia - Revista Eletrônica de Relações Internacionais do Centro Universitário Unieuro

ISSN: $1809-1261$

UNIEURO, Brasília, número 13, 2014, pp. 159-201.

suas respostas. A militarização da questão das drogas na Colômbia incide diretamente nas discussões acerca da diferenciação entre segurança e defesa.

O Conselho de Defesa Sul-Americano tem reforçado a sua condição de tratar apenas temas relacionados à defesa buscando evitar a militarização de questões de segurança. Porém, definir os limites entre segurança e defesa não é tarefa simples, pelo contrário, constitui-se um fundamento para o avanço da cooperação de defesa na região. O desafio não é uma definição comum de defesa e segurança por imposição de uma única percepção, mas sim pelo consenso e reconhecimento das múltiplas perspectivas. Nesse sentido, a discussão acerca da segurança pública é fundamental. A proposta não é que os Ministros da Defesa discutam segurança pública, mesmo porque grande parte dos países da região não atribui essa função a este Ministério, mas, que a cooperação nessa área seja aprofundada vista a realidade regional. Como é possível falar em zona de paz em uma das regiões mais violentas do mundo? A questão das drogas não está limitada a região andina e a violência social não é realidade somente de um país. É necessário buscar soluções e, consideradas as particularidades de cada Estado, elas podem ser pensadas no contexto da cooperação regional. Dessa forma, a continuidade e aprofundamento da cooperação no âmbito do Conselho Sul-Americano em Matéria de Segurança Cidadã, Justiça e Coordenação de Ações contra a Delinquência Organizada Transnacional e do Conselho sobre o Problema Mundial das Drogas, assim como o desenvolvimento de um trabalho conjunto entre eles, é fundamental.

Mais do que o núcleo do subcomplexo Norte Andino a questão das drogas é um problema do complexo de segurança sul-americano. Transbordam as fronteiras não apenas as preocupações com o cultivo e venda das drogas, com a atuação dos guerrilheiros, com o tráfico de armas e a violência, mas também com a presença militar dos Estados Unidos na região. Segundo Buzan e Wæver (2003), não havia um projeto integrador que unisse os dois subcomplexos regionais. Hoje, a UNASUL e o CDS compreendem iniciativas que reúnem os doze países da região. Porém, considerando que os arranjos de integração na 


\section{Artigo original}

Hegemonia - Revista Eletrônica de Relações Internacionais do Centro Universitário Unieuro

ISSN: $1809-1261$

UNIEURO, Brasília, número 13, 2014, pp. 159-201.

América do Sul têm sido arranjos intergovernamentais e não supranacionais, a vontade política dos atores é fundamental. Os princípios de flexibilidade e gradualidade presentes tanto na UNASUL quanto no CDS reconhecem as diferenças entre os Estados sul-americanos, porém não devem justificar uma inércia ou retrocesso dos processos de integração.

O Conselho de Defesa tem obtido alguns resultados como, a criação do Centro de Estudos Estratégicos de Defesa, a realização de cursos e seminários, formação de grupos de trabalho para discutir variados aspectos e a implantação de um sistema para medir os gastos militares dos países da região. Este último adquire particular relevância em um cenário onde alguns países demonstraram preocupações acerca de uma possível corrida armamentista na região. Nos planos de ação do CDS também se destacam iniciativas na esfera de produção tecnológica. É relevante mencionar que a integração das indústrias de defesa dos países da região é um dos objetivos do órgão. Nesse sentido, o Brasil lideraria o processo, pois sua indústria de defesa é a mais desenvolvida na América do Sul, que em geral comporta indústrias bastante limitadas. Esse é um processo complexo que demanda profissionais capacitados, transferência tecnológica e recursos, sendo que os orçamentos para despesas militares dos países da região são limitados e parcela significativa deles é destinada ao pagamento de pessoal. É preciso vontade política. O custo é elevado, mas, o incentivo a produção de conhecimento e o desenvolvimento tecnológico estão diretamente relacionados com o aumento da autonomia e o desenvolvimento nacional e regional.

De forma geral, no complexo regional de segurança da América do Sul o Brasil tem um papel central, mantendo-o unido ao definir a região como prioridade da sua política externa, empreender iniciativas como a UNASUL e o CDS e promover o discurso contrário a intervenção de potências extraregionais nos assuntos do subcontinente. A liderança brasileira, ainda que modesta em muitos aspectos, o que alguns estudiosos justificam pela limitação dos próprios recursos militares e econômicos do país, é fundamental para a 


\section{Artigo original}

Hegemonia - Revista Eletrônica de Relações Internacionais do Centro

Universitário Unieuro

ISSN: $1809-1261$

UNIEURO, Brasília, número 13, 2014, pp. 159-201.

continuidade e aprofundamento dos processos de integração.

A América do Sul ainda está longe de ser uma comunidade de segurança consolidada onde existe uma interdependência profunda e uma identidade compartilhada. Para além das hipóteses de conflitos tradicionais que existem, ainda que não signifique que a região esteja propensa a guerra, problemas como o narcotráfico e a violência social geram instabilidade para complexo de segurança regional. No entanto, se pensarmos que a construção de uma comunidade de segurança é um processo, a criação do Conselho de Defesa constitui-se um passo relevante para o fortalecimento da confiança mútua e um marco na medida em que os doze países da região conformaram um espaço para discutir e pensar soluções conjuntas para os seus problemas. A consolidação do CDS com o aprofundamento da cooperação desenvolvida nessa instância e, de forma geral, o aprofundamento da cooperação no âmbito da UNASUL contribui para estabilidade regional, mitigando desconfianças e minimizando os riscos de intervenção de potências extra-regionais.

\section{REFERÊNCIAS}

ADLER, Emanuel; BARNETT, Michael. Security Comunities. Cambridge: Cambridge University Press, 1998.

BANDEIRA, Luiz Alberto Moniz. Geopolítica e política exterior: Estados Unidos, Brasil e América do Sul. Brasília: Fundação Alexandre de Gusmão, 2009.

BBC. Corte de Haia põe fim a disputa histórica entre Chile e Peru. Disponível em:

http://www.bbc.co.uk/portuguese/noticias/2014/01/140127_haia_decisao_chi le_peru_fn.shtml>. Acesso em: mai. De 2014.

BUZAN, Barry; W/EVER, Ole. Regions and Powers: the Structure of International Security. Cambridge: Cambridge University Press, 2003.

Buzan, Barry, Ole Weaver, e Jaap de Wilde. Security: A New Framework of Analysis. Boulder: Lynne Rienner Publishers, 1998. 


\section{Artigo original}

Hegemonia - Revista Eletrônica de Relações Internacionais do Centro

Universitário Unieuro

ISSN: $1809-1261$

UNIEURO, Brasília, número 13, 2014, pp. 159-201.

CALLE, Fabián. El espacio Sudamericano como "zona de paz" a preservar frente a factores de turbulencia intra y extra-regionales. 2010. Disponível em: < http://www.cari.org.ar/pdf/espacio_sudamericano.pdf>. Acesso em: out. de 2013.

CEED. Primera Reunión de la Escuela Suramericana de Defensa. Disponível em: < http://www.ceedcds.org.ar/Espanol/04-Eventos/0031-Eventos.html>. Acesso em: mai. 2014.

CEED. Presentación del Registro de Suramericano de Gasto de Defensa al Consejo de Defensa Suramericano. Disponível em: < http://www.ceedcds.org.ar/Espanol/04-Eventos/0009-Eventos.html>. Acesso em: abr. de 2014.

CEED. Unasur y la cooperación en la lucha contra el crimen organizado transnacional y los delitos transfronterizos. Informe del Centro de Estudios Estratégicos de Defensa del Consejo de Defensa Suramericano, Acerca del Crimen Organizado Transnacional y Otras Nuevas Amenazas a la Seguridad Regional Disponível em: <http://www.ceedcds.org.ar/Espanol/09Downloads/CRIMEN_ORGANIZADO.pdf>. Acesso em: mai. De 2014.

CONSELHO DE DEFESA SUL-AMERICANO. Planos de Ação 2014. Disponível em: $<$ http://www.ceedcds.org.ar/Espanol/07-

Consejo_Defensa_Suramericano/02_Plan_de\%20Accion.html>. Acesso em mai. De 2014.

CERVO, Amado Luiz. Inserção Internacional: formação dos conceitos brasileiros. São Paulo: Saraiva, 2008.

DEUTSCH, Karl (1957), Political Community and the North Atlantic Area, Princeton, Princeton University Press.

FLEMES, Daniel. Notas Teóricas sobre a Formação de uma Comunidade de Segurança entre a Argentina, o Brasil e o Chile. Revista de Sociologia e Política (Curitiba), no. 24, 2005. Disponível em: <http://www. scielo.br/scielo.php?pid=S0104-

44782005000100014\&script=sci_arttext\&tIng=en\#nt01>. Acesso em: 05 mai. 2014.

FLEMES, Daniel; NOLTE, Detlef; WHENER, Leslie. Uma comunidad de seguridad regional en formación: La UNASUR y su Consejo de Defensa. Estudios Internacionales 170 (2011) - ISSN 0716-0240 • 105-127 Instituto de Estudios Internacionales - Universidad de Chile. 


\section{Artigo original}

Hegemonia - Revista Eletrônica de Relações Internacionais do Centro

Universitário Unieuro

ISSN: $1809-1261$

UNIEURO, Brasília, número 13, 2014, pp. 159-201.

FUCILLE, REZENDE. Complexo Regional de Segurança: Uma nova perspectiva. 2013. Disponível em: <http://www.scielo.br/pdf/cint/v35n1/a03v35n1.pdf>.

HABDUL-HAK. Ana Patrícia Neves. O Conselho de Defesa Sul-Americano (CDS): Objetivos e interesses do Brasil. Brasília. FUNAG: 2013.

HOLSTI, Kalevi. Analyzing an Anomaly: War, Peace and the State in South America. In: The State, War, and the State of War. Cambridge University Press, 1996.

HURRELL, Andrew. An emerging security community in South America? In: ADLER, Emanuel; BARNETT, Michael (Ed.). Security Communities. Cambridge: Cambridge University Press, 1998

KACOWICZ, Arie Marcelo. Zones of Peace in the Third World: South America and West Africa in Comparative Study. Nova York: State of New York University Press, 1998.

LAFER, Celso. Discurso do Professor Celso Lafer, Ministro de Estado das Relações Exteriores, na Cerimônia de Comemoração dos Dez Anos da Agência Brasileiro-Argentina de Contabilidade e Controle - ABACC (Buenos Aires, Argentina, 14 de agosto de 2001). Disponível em: < http://www.itamaraty.gov.br/sala-de-imprensa/notas-aimprensa/2001/08/14/discurso-do-professor-celso-lafer-ministro-de/printnota>. Acesso em: 15 abr. 2014.

MAGALHÃES, Diego Trindade d'Ávila. Comunidade de segurança: a teoria no conceito. Carta Internacional. Vol. 7, n. 2, jul.-dez. 2012 [p. 81 a 98].

MEDEIROS FILHO, Oscar. Entre a cooperação e a dissuasão: políticas de defesa e percepções militares na América do Sul. 2010. 000 f. Tese (Doutorado) Faculdade de Filosofia, Letras e Ciências Humanas, Universidade de São Paulo, São Paulo, 2010.

MINISTERIO DE DEFENSA DE ARGENTINA. La cuestión Malvinas en el contexto de la Política de Defensa. Disponível em: < http://www.mindef.gov.ar/mindef_malvinas/index.html\#ma02>. Acesso em: mai. De 2014.

NATHAN, Laurie. Security Communities and the problem od Domestic Instability. $2004 . \quad$ Disponível em: <http://eprints.Ise.ac.uk/28204/1/wp55.pdf>.Acesso em: 05 mai. 2014. 


\section{Artigo original}

Hegemonia - Revista Eletrônica de Relações Internacionais do Centro

Universitário Unieuro

ISSN: $1809-1261$

UNIEURO, Brasília, número 13, 2014, pp. 159-201.

PAGLIARI; Graciela De Conti. Segurança e defesa na América do Sul: A cooperação regional e 0 papel do Brasil. Disponível em: < http://www.revistas.unilasalle.edu.br/index.php/Dialogo/article/view/68>. Acesso em mai. de 2014.

. Segurança hemisférica: uma discussão sobre a validade e atualidade de seus mecanismos institucionais. Disponível em: < http://www.scielo.br/pdf/rbpi/v49n1/a02v49n1.pdf>. Acesso em abr. de 2014.

PAGLIARI; Graciela De Conti; FONTES, Peterson Wilson. Gastos militares na América do Sul: considerações acerca dos investimentos no período pósGuerra Fria. Disponível em: < http://cnm.ufsc.br/files/2013/08/Gastosmilitares-AS-Graciela-C-Pagliari.pdf>. Acesso em out. de 2013.

PINTA GAMA, Marcos Vinícius. O Conselho de Defesa Sul-Americano e sua Instrumentalidade. In. ALSINA JUNIOR, João Paulo Soares; JOBIM, Nelson Azevedo; ETCHEGOYEN, Sergio Westphalen. Segurança Internacional: perspectivas brasileiras. Rio de Janeiro: Editora FGV, 2010.

RIVERA. La relación entre integración y seguridad en el Mercosur y sus poyecciones hacia sudamérica. Disponível em: <http://www.scielo.org.co/pdf/ries/v8n1/v8n1a13.pdf>.

SAINT-PIERRE, Hector Luis. Grandes tendências da segurança internacional contemporânea. In. ALSINA JUNIOR, João Paulo Soares; JOBIM, Nelson Azevedo; ETCHEGOYEN, Sergio Westphalen. Segurança Internacional: perspectivas brasileiras. Rio de Janeiro: Editora FGV, 2010.

SAINT-PIERRE, Hector Luis. La defensa em La política exterior de Brasil: El Consejo Sulamericano y La Estratégia Nacional de Defensa. Madri: Documento de Trabajo del Real Instituto Elcano, n. 50/2009, outubro, 2009.

SIPRI Yearbook 2013. Disponível em: < http://www.sipri.org/yearbook/2013/files/SI

PRIYB13Summary.pdf>. Acesso em: out. de 2013.

SIPRI Military Expenditure Database, SIPRI 2013. Disponível em: < http://www.sipri.org >. Acesso em: out. de 2013.

SOLMIRANO, Carina; PERLO-FREEMAN, Sam. Is South America on the brink of an arms race?. Disponível em: < http://www.sipri.org/media/newsletter/essay/jan10

>. Acesso em: out. de 2013. 


\section{Artigo original}

Hegemonia - Revista Eletrônica de Relações Internacionais do Centro

Universitário Unieuro

ISSN: $1809-1261$

UNIEURO, Brasília, número 13, 2014, pp. 159-201.

UNASUL. Estatuto do Conselho de Defesa Sul-Americano da UNASUL. 2008. Disponível em: < http://www.ceedcds.org.ar/Portugues/09-Downloads/PORTESTATUTO_CDS.pdf>. Acesso em: mar. de 2014.

UNODC. Global Study on Homicide. 2013. Disponível em: < http://www.unodc.org/documents/gsh/pdfs/2014_GLOBAL_HOMICIDE_BOOK _web.pdf >. Acesso em: mai. de 2014.

UNODC. International Homicide count and rate per 100,000 population, by country/territory (2000-2012).

Disponível em: http://www.unodc.org/gsh/en/data.html>. Acesso em: mai. de 2014.

VILLA, Rafael Duarte; VIGGIANO, Juliana. Trends in South American weapons purchases at the beginning of the new Millennium. Revista Brasileira de Política Internacional. 55 (2): 28-47. 2012.

WENDT, Alexander. Social Theory of International Politics. Cambridge: Cambridge University Press, 1999.

Anarchy is what the states make of it: the social construction of Power politics. 1992. Disponível em: $<$ http://labmundo.org/disciplinas/WENDT_anarchy_is_what_states_ make_of_it.pdf >. Acesso em: 07 set. 2013 